\title{
Characterization of the Interactions Between Cucumber mosaic virus and Potato virus $Y$ in Mixed Infections in Tomato
}

\author{
Tiziana Mascia, ${ }^{1,2}$ Fabrizio Cillo, ${ }^{2}$ Vilma Fanelli, ${ }^{1}$ Mariella Matilde Finetti-Sialer, ${ }^{1}$ Angelo De Stradis, ${ }^{2}$ \\ Peter Palukaitis, ${ }^{3,4}$ and Donato Gallitelli ${ }^{1,2}$ \\ ${ }^{1}$ Dipartimento di Protezione delle Piante e Microbiologia Applicata, Università degli Studi di Bari, Via Amendola 165/A, \\ 70126 Bari, Italy; ${ }^{2}$ Istituto di Virologia Vegetale del CNR, Unità Organizzativa di Bari, Via Amendola 165/A, 70126 Bari, Italy; \\ ${ }^{3}$ Scottish Crop Research Institute, Invergowrie DD2 5DA, U.K.; ${ }^{4}$ PVGB, Division of Environmental and Life Sciences, Seoul \\ Women's University, Seoul 139-774, South Korea
}

Submitted 16 March 2010. Accepted 26 May 2010.

\begin{abstract}
Mixed infection with the SON41 strain of Potato virus $Y$ (PVY-SON41) in tomato increased accumulation of RNAs of strains Fny and LS of Cucumber mosaic virus (CMV-Fny and CMV-LS, respectively) and enhanced disease symptoms. By contrast, replication of PVY-SON41 was downregulated by CMV-Fny and this was due to the CMV-Fny 2b protein. The $C M V-F n y \Delta 2 b$ mutant was unable to systemically invade the tomato plant because its movement was blocked at the bundle sheath of the phloem. The function needed for invading the phloem was complemented by PVY-SON41 in plants grown at $22^{\circ} \mathrm{C}$ whereas this complementation was not necessary in plants grown at $15^{\circ} \mathrm{C}$. Mutations in the $2 \mathrm{~b}$ protein coding sequence of CMV-Fny as well as inhibition of translation of the $2 a / 2 b$ overlapping region of the $2 \mathrm{a}$ protein lessened both the accumulation of viral RNAs and the severity of symptoms. Both of these functions were complemented by PVY-SON41. Infection of CMV-Fny supporting replication of the Tfn-satellite RNA reduced the accumulation of CMV RNA and suppressed symptom expression also in plants mixed-infected with PVY-SON41. The interaction between CMV and PVYSON41 in tomato exhibited different features from that documented in other hosts. The results of this work are relevant from an ecological and epidemiological perspective due to the frequency of natural mixed infection of CMV and PVY in tomato.
\end{abstract}

Cucumber mosaic virus (CMV) and viruses of different taxa often have been found to act synergistically in legumes, cucurbits, and solanaceous crops (Palukaitis and Garcia-Arenal 2003; Wege and Siegmund 2007). In most of such mixed infections, the synergism consisted of the exacerbation of disease symptoms, the increase of virus titer, and the complementation of movement defects due to host restrictions, so that one or both the viruses spread systemically and accumulate at high

Present address of T. Mascia and D. Gallitelli: Dipartimento di Biologia e Patologia Vegetale, Università degli Studi Bari, Via Amendola 165/A, 70126 Bari, Italy.

Present address of M. M. Finetti-Sialer: Istituto di Genetica Vegetale del CNR, Via Amendola 165/A, 70126, Bari, Italy.

Corresponding author: Tiziana Mascia; E-mail: tizianamascia@email.it; Telephone + 39080544 2913; Fax + 390805442906 . levels in nonhost plants and resistant varieties (Palukaitis and Kaplan 1997; Ryabov et al. 2001; Saenz et al. 2002; Palukaitis and Garcia-Arenal 2003; Wege and Siegmund 2007). The increase of virus titer in mixed infections can also modify other viral traits such as the plant-to-plant insect transmission rate of the two viruses and may be a determinant in field spread and for their evolution in epidemics (Rochow 1972; Martin and Elena 2009).

Many examples of plant viral synergism in different host species involve CMV and a member of the Potyvirus group and have been described in detail in tobacco and cucurbit plants (Poolpol and Inouye 1986; Pruss et al. 1997; Wang et al. 2002). In tobacco, Potato virus $Y$ (PVY) stimulated CMV accumulation but CMV did not enhance that of PVY (Palukaitis and Kaplan 1997) while, in another instance, CMV complemented the mobility defects of PVY, also increasing its titer in plant tissues (Ryang et al. 2004). The movement restriction of the M strain of CMV was also abolished in zucchini squash by Zucchini yellow mosaic virus (ZYMV) (Choi et al. 2002). In zucchini squash and melon plants with mixed infection of CMV with either ZYMV or Watermelon mosaic virus (WMV), CMV RNA was shown to induce a severe pathological response and showed an increase in virus titer compared with single infection, whereas no such synergistic effects were observed for the two Potyvirus spp. (Wang et al. 2002). Similar results have been described with cucumber plants and protoplasts (Poolpol and Inouye 1986) in which a nonreciprocal effect of mixed infections has been reported, either at the single-cell level or in the whole host plant.

Mixed infections of PVY and CMV, often carrying its satellite RNA (CMV-satRNA), were detected in commercial fields of tomato crops during the CMV outbreaks that occurred in Italy in the mid-1980s (Gallitelli et al. 1988; Gallitelli 2000). In spite of the high frequency and great economic relevance of such mixed infections, there are no reports on the interactions between CMV and PVY in this host. The only available data in tomato focused on plants mixed-infected with CMV and the Begomovirus sp. Abutilon mosaic virus (Wege and Siegmund 2007).

In this study, we report the effects of interactions between CMV and PVY in tomato, which reveal new features that are unique to this model and may be relevant for further understanding of viral interactions in plants with mixed infection.

We used the SON41 strain of PVY that induced very mild symptoms in tomato and two CMV strains (CMV-Fny and 
CMV-LS) characterized by different levels of aggressiveness in this host, exhibiting, overall, approximately 71 to $76 \%$ nucleotide sequence identity. Because the $2 \mathrm{~b}$ protein of CMV has been characterized as an important pathogenicity determinant and suppressor of RNA silencing (SRS), we also used a number of CMV-Fny mutants to investigate the importance of specific domains within the $2 \mathrm{~b}$ protein for symptom induction and interaction with PVY-SON41. Subsequently, we examined the outcome of the trilateral interaction of PVY-SON41, CMV-Fny, and CMV-satRNA. This has been studied previously in cucurbits but not in tomato and it might have important ecological and epidemiological implications because some variants of CMV-satRNA can induce an exacerbation or amelioration of disease symptoms in this host (Palukaitis and Garcia-Arenal 2003).

Although some of the experimental observations confirmed those seen in other plant hosts, there also were novel findings observed at the single-cell level, at an early stage of mixed infection, and in systemic infection at 28 days postinoculation (dpi). At this stage of infection, the accumulation of PVYSON41 RNA was reduced significantly, and this was due to the CMV $2 b$ function. In addition, this study showed several unique features that differed from those described for mixed infection of PVY and CMV in tobacco and cucumber: i) PVYSON41 complemented CMV-Fny $\Delta 2 b$ infection, enabling its movement through the plant; ii) PVY-SON41 did not affect the level of CMV-satRNA, while CMV-satRNA mitigated CMVFny 2b-mediated inhibition of PVY-SON41; and iii) the CMVFny $2 \mathrm{a} / 2 \mathrm{~b}$ overlapping region, which was not translated in the CMV-Fny $\Delta 2 \mathrm{a}$ mutant, lessened both the accumulation of viral RNAs and the severity of symptoms, thus unraveling a role of this sequence in the pathogenicity of CMV in tomato. These results do not overlap with those reported in other instances by using different hosts, CMV strains, and CMV-satRNA and Potyvirus spp., thus highlighting novel interactions involved in mixed infections in tomato.

\section{RESULTS}

Symptom responses in double-infected tomato plants.

To examine the effects of the CMV $2 b$ gene on symptom induction in tomato plants, we established an experimental approach using two strains of CMV (Fny and LS) in single and mixed infection with PVY-SON41. This strain of PVY, which was isolated originally from Solanum nigrum, induced very mild mosaic symptoms on the first two systemically infected leaves within 15 dpi (Fig. 1). The plants then gradually recovered from this condition and no symptoms were visible in the new leaves at 28 dpi. PVY-SON41 was selected specifically for this study because it was considered appropriate for evaluating any symptom changes in tomato infected by different combinations of inocula.

The disease phenotype of plants infected by CMV-Fny was more severe than that induced by CMV-LS, as reported previously (Palukaitis 1988; Lewsey et al. 2007; Cillo et al. 2009). Within 12 to 15 dpi, CMV-Fny induced an accentuated reduction of leaflet blades (i.e., filiformism, commonly denoted as leaf shoestring) (Fig. 1) and of whole plant growth, while plants infected by CMV-LS developed much less filiformism and deformation (Fig. 1) and no reduction in plant growth was observed. Plants challenged by CMV-LS plus PVY-SON41 exhibited stunting and leaf malformations but not filiformism (Fig. 1) whereas, compared with CMV-Fny single infections, plants with mixed infection with PVY-SON41 exhibited an exacerbation of systemic symptoms described above (Fig. 1). Infection by the CMV-Fny $\Delta 2 \mathrm{~b}$ (deletion mutant) was asymptomatic whereas, in mixed-infected plants, symptoms were similar to those elicited by PVY-SON41 (Fig. 1).

\section{CMV and PVY accumulation patterns in tomato protoplasts.}

To study the interactions between the two viruses in tomato, we first estimated the accumulation levels of the various viral RNAs in single cells. At $24 \mathrm{~h}$ postinoculation (hpi), total RNA was extracted from tomato protoplasts, reverse-transcribed, and used as a template for quantitative real-time polymerase chain reaction $(\mathrm{PCR})$. Real-time reverse-transcription PCR tests and electrophoretic analyses confirmed that each primer pair amplified a DNA fragment of the expected size with no additional products, as demonstrated by the single peak shown in the respective dissociation curves and single bands in agarose gels. As a further validation, the nucleotide sequence of each amplicon was determined, exhibiting $100 \%$ identity with the expected sequence. Standard curves generated for each target sequence from decimal dilution series of template cDNA
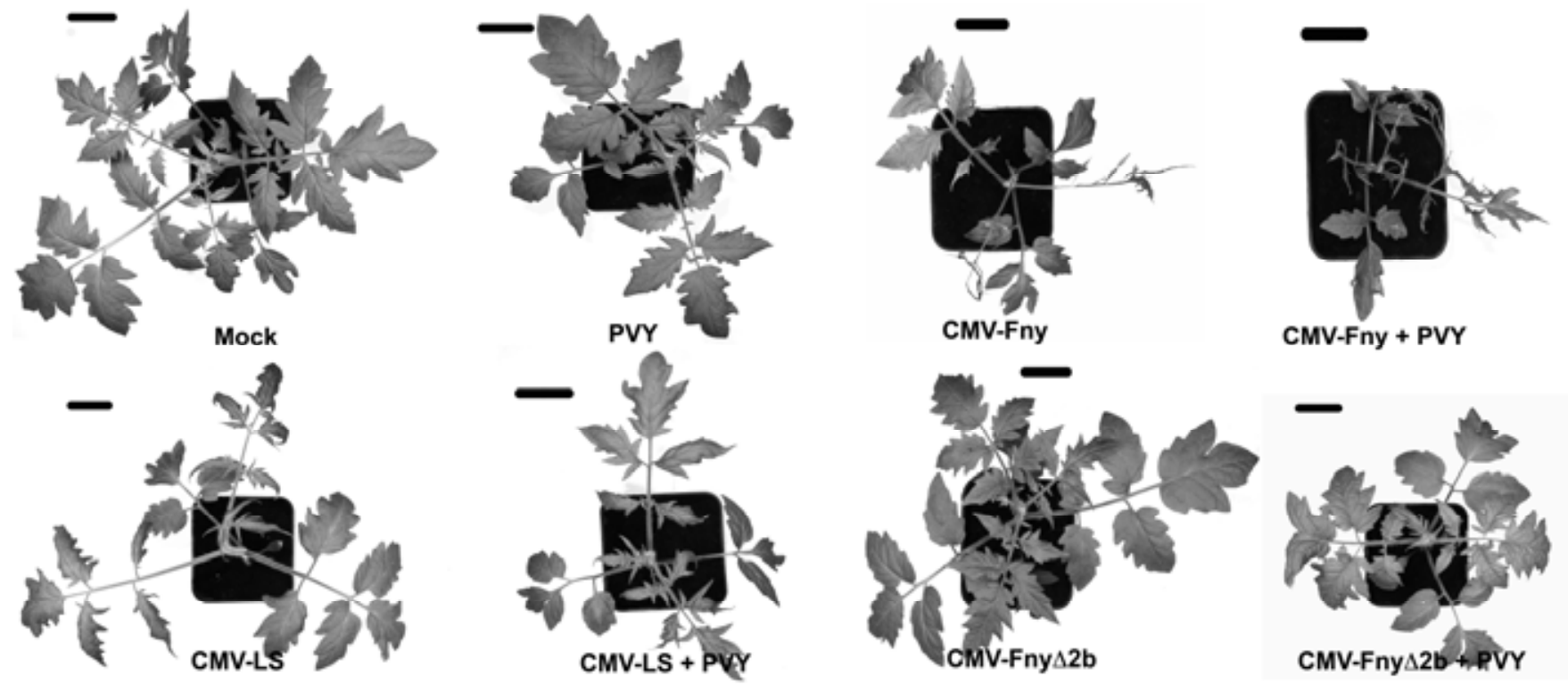

Fig. 1. Symptoms induced by the different combinations of inocula in tomato plants (scale bars $=4 \mathrm{~cm}$ ) by 15 days postinoculation. CMV $=$ Cucumber mosaic virus and $\mathrm{PVY}=$ Potato virus $Y$-SON41. 
were parallel, all showing a slope value within the range -3.27 to -3.47 , indicating a very similar PCR efficiency (between 99 and $105 \%$ ).

The relative levels of CMV-Fny RNA 3 and PVY-SON41 genomic RNA in single infections at 24 hpi were set arbitrarily to 1 (Fig. 2, CMV 24 and PVY 24). At $24 \mathrm{hpi}$, the presence of PVY-SON41 enhanced the accumulation of CMV-Fny RNA 3 by twofold (Fig. 2, CMV+PVY 24 versus CMV 24). In the set of experiments in which CMV-Fny was substituted by CMVFny $\Delta 2 \mathrm{~b}$, the RNA 3 of the CMV mutant remained at very low levels in either single or mixed-infected protoplasts (Fig. 2, CMV- $\Delta 2$ b 24 and CMV- $\Delta 2$ b + PVY 24). By contrast, CMV-Fny

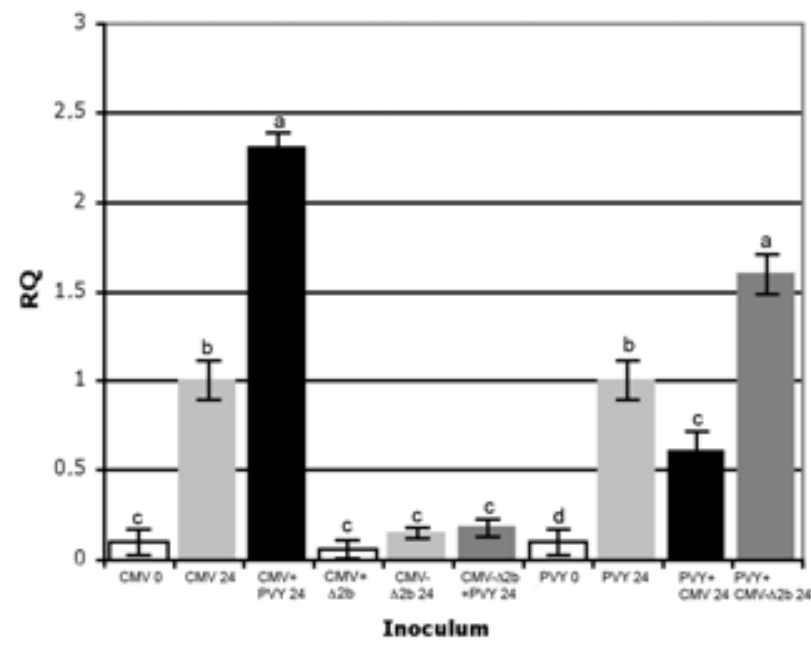

Fig. 2. Determination of the relative quantity (RQ) of the Cucumber mosaic virus (CMV)-Fny, CMV-Fny $\Delta 2 \mathrm{~b}, \mathrm{CMV}-\mathrm{Fny}+$ Potato virus $Y$ (PVY), CMV-Fny $\Delta 2 \mathrm{~b}+\mathrm{PVY}$, and PVY-SON41 RNA accumulation levels at 0 and $24 \mathrm{~h}$ postinoculation (hpi) in tomato protoplasts infected by the viruses, alone or in combination. The values of fluorescence were first normalized on the accumulation level of the actin mRNA ( $\Delta$ cycle threshold $\left.[\mathrm{Ct}]=\mathrm{Ct}_{\mathrm{ACT}}-\mathrm{Ct}_{\text {target RNA }}\right)$ and then used to determine the relative quantification of each target RNA with a calibrator, according to the for-

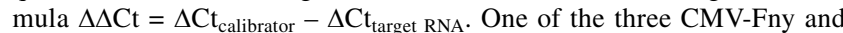
PVY-SON41 samples served as calibrator (RQ set to 1) for the respective virus. RQ for each target was deduced by the formula expression $2^{-}$ $\Delta \Delta \mathrm{Ct}$. Columns represent mean RQ values from three biological replicates each extracted from 0.75 to $1 \times 10^{6}$ protoplasts. Vertical bars represent the standard error and different letters represent statistically significant differences values according to analysis of variance $(P<0.05)$ (Tukey post-hoc test) and CMV-Fny $\Delta 2 \mathrm{~b}$ showed a differential effect on PVY replication which, compared with single infections, was reduced by half at 24 hpi in mixed infection with CMV-Fny whereas it was doubled in the presence of the CMV- $\Delta 2 \mathrm{~b}$ mutant (Fig. 2, PVY + CMV- $\Delta 2$ b 24 versus PVY + CMV 24). In summary, the following effects were observed at the single-cell level: i) the presence of PVY-SON41 in mixed infection increased CMV-Fny replication while that of the Potyvirus sp. was reduced, ii) CMV-Fny could benefit from PVY-SON41 mixed infection only if CMV produced a $2 b$ protein, iii) the CMV $2 b$ protein was necessary for efficient CMV replication in tomato protoplasts and was involved in an adverse effect on PVY accumulation, and iv) PVY-SON41 utilized some functions provided by the CMV mutant to enhance its own replication.

\section{CMV and PVY RNA accumulation levels in infected leaf tissues correlate with changes in disease symptom severity.}

We examined the accumulation levels of viral RNAs in single and mixed infections at $7 \mathrm{dpi}$ in tomato cotyledons and at 28 and 60 dpi in systemically infected leaves of plants inoculated first with PVY-SON41 and, 3 days later, with either CMV-Fny or CMV-LS. Northern blot analyses of total RNAs extracted from inoculated tissues at 7 dpi showed that RNAs of both CMV strains accumulated essentially at the same level, regardless of the presence or absence of the Potyvirus sp. (Table 1). A similar pattern was found with CMV-Fny $\Delta 2 b$, although its RNAs accumulated to a somewhat lesser extent and also regardless of the presence or absence of PVY-SON41 (Table 1). PVY-SON41 RNA accumulation levels varied for each inoculum combination. In mixed infection with either CMV strain, PVY-SON41 RNA accumulated to slightly higher levels than in single infection, while PVY-SON41 RNA accumulation was enhanced in mixed infection with CMV-Fny $\Delta 2 \mathrm{~b}$ (Table 1). These results are congruent with those obtained at the singlecell level.

At 28 dpi, RNAs 3 and 4 of CMV-Fny and CMV-LS were three- and twofold more abundant, respectively, during mixed infection with PVY-SON41 than in single-infected plants (Table 1), and this pattern correlated positively with the increase in disease severity.

The CMV-Fny $\Delta 2 \mathrm{~b}$ mutant was unable to move systemically (discussed below). In mixed infection with PVY-SON41, the CMV mutant moved but its RNAs accumulation levels were between six- and eightfold lower than the corresponding RNAs of CMV-Fny (Table 1). At this infection time point, the abun-

Table 1. Estimates of abundance of viral RNAs at 7, 28, and 60 days postinoculation (dpi) in tomato leaf tissues upon infection with different inoculum (viral RNA) combinations ${ }^{2}$

\begin{tabular}{|c|c|c|c|c|c|c|c|c|}
\hline $\begin{array}{l}\text { Inoculum, } \\
\text { time }\end{array}$ & Mock & CMV-Fny & CMV-LS & CMV-Fny $\Delta 2 b$ & PVY & $\begin{array}{c}\text { PVY + } \\
\text { CMV-Fny }\end{array}$ & $\begin{array}{c}\text { PVY + } \\
\text { CMV-Fny } \Delta 2 b\end{array}$ & $\begin{array}{c}\text { PVY + } \\
\text { CMV-LS }\end{array}$ \\
\hline \multicolumn{9}{|c|}{ CMV RNA 3} \\
\hline $7 \mathrm{dpi}$ & $0.01 \pm 0.001 \mathrm{e}$ & $30.03 \pm 2.6 \mathrm{~b}$ & $25.13 \pm 3.8 \mathrm{~b}$ & $22.13 \pm 1.8 \mathrm{~b}$ & - & $31.63 \pm 2.3 b$ & $24.13 \pm 1.1 \mathrm{~b}$ & $30.53 \pm 3.4 b$ \\
\hline $28 \mathrm{dpi}$ & $\ldots$ & $26.78 \pm 7.25 b$ & $15.30 \pm 5.75 c$ & - & - & $85.56 \pm 3.47 \mathrm{a}$ & $10.53 \pm 1.75 c$ & $26.30 \pm 5.35 b$ \\
\hline $60 \mathrm{dpi}$ & $\ldots$ & $13.75 \pm 3.55 \mathrm{c}$ & $7.89 \pm 1.23 \mathrm{~d}$ & - & - & $89.66 \pm 1.42 \mathrm{a}$ & $12.03 \pm 1.3 \mathrm{c}$ & $24.25 \pm 4.20 \mathrm{~b}$ \\
\hline \multicolumn{9}{|c|}{ CMV RNA 4} \\
\hline 7 dpi & $0.01 \pm 0.001 \mathrm{e}$ & $30.03 \pm 2.6 b$ & $25.13 \pm 3.8 b$ & $22.13 \pm 1.8 \mathrm{~b}$ & - & $31.63 \pm 2.3 \mathrm{~b}$ & $24.13 \pm 1.1 \mathrm{~b}$ & $30.53 \pm 3.4 \mathrm{~b}$ \\
\hline $28 \mathrm{dpi}$ & & $34.82 \pm 9.73 b$ & $18.50 \pm 5.76 c$ & & - & $106.02 \pm 3.01 \mathrm{a}$ & $18.50 \pm 5.76 \mathrm{c}$ & $36.50 \pm 5.1 \mathrm{~b}$ \\
\hline $60 \mathrm{dpi}$ & .. & $17.41 \pm 2.37 \mathrm{c}$ & $8.11 \pm 1.14 \mathrm{~d}$ & $\ldots$ & - & $113.52 \pm 5.81 \mathrm{a}$ & $17.60 \pm 4.65 \mathrm{c}$ & $35.72 \pm 5.25 b$ \\
\hline \multicolumn{9}{|l|}{ PVY-SON41 } \\
\hline $7 \mathrm{dpi}$ & $0.01 \pm 0.001 \mathrm{e}$ & - & - & $\ldots$ & $80.51 \pm 7.2 \mathrm{~d}$ & $111.89 \pm 4.0 \mathrm{~b}$ & $135.30 \pm 5.7 \mathrm{a}$ & $112.00 \pm 4.9 \mathrm{~b}$ \\
\hline 28dpi & $\ldots$ & - & - & $\ldots$ & $149.02 \pm 16.67 \mathrm{a}$ & $96.71 \pm 2.48 c$ & 103. $25 \pm 2.3 \mathrm{c}$ & $101.50 \pm 2.4 \mathrm{c}$ \\
\hline $60 \mathrm{dpi}$ & $\ldots$ & - & - & $\ldots$ & $89.41 \pm 2.63 \mathrm{~d}$ & $130.55 \pm 3.55 \mathrm{a}$ & $113.30 \pm 2.7 \mathrm{~b}$ & $112.32 \pm 5.3 b$ \\
\hline
\end{tabular}

${ }^{\mathrm{z}}$ Intensity data of the chemiluminescent signals (optical density $\times \mathrm{mm}^{2}$ ) were recorded with a ChemiDoc image analysis system (Bio-Rad) for the quantification of viral RNAs after the hybridization of RNA gel-blots with the Cucumber mosaic virus (CMV)- and Potato virus Y (PVY)-specific riboprobes. Values are mean \pm standard deviation of signal intensity for each viral RNA from three RNA preparations, each extracted from a different infected plant. Values at $7 \mathrm{dpi}$ are in the inoculated leaf whereas values at 28 and $60 \mathrm{dpi}$ are in systemic leaves. Different letters (for each viral RNA) represent a significant difference of the means according to an analysis of variance test $(P<0.05) ;-$ and $\ldots$ designate no detection and not done, respectively. 
dance of PVY-SON41 RNA in mixed infection was reduced by one-third compared with plants infected by the Potyvirus sp. alone (Table 1), as observed also at the single-cell level.

The overall pattern described for both CMV-Fny and CMVLS RNA remained unchanged at 60 dpi because both CMV strains were upregulated in the presence of the Potyvirus sp. (Table 1). By contrast, PVY-SON41 RNA accumulation levels decreased by one-third in single infections between 28 and 60 dpi, whereas they increased by one-third in the presence of CMV-Fny (Table 1), which represents a reversal with regard to what was observed at the earlier time point. Experiments performed with an inverted order of virus inoculation, or with the two viruses inoculated simultaneously, always produced similar results (data not shown).

In summary, the positive effects of PVY-SON41 on CMVFny RNA accumulation and, at the same time, the inhibitory effects of CMV-Fny on PVY-SON41 RNA accumulation were consistent with the observations made in single cells and at 28 dpi in leaf tissues. Surprisingly, both viruses seemed to profit from double infections in leaves of tomato plants at $60 \mathrm{dpi}$. This was seen also in tissue prints of transversally cut tissue at each internode of the stem and leaf petiole along the whole plant, where the distribution of CMV-Fny and PVY-SON41 at 60 dpi seemed much more uniform in mixed infection (data not shown). This was true even for CMV-Fny $\Delta 2 b$, which itself showed a poor accumulation, whereas it strongly enhanced the distribution of PVY-SON41 in the upper leaves.

\section{PVY complements CMV-Fny $\Delta 2 b$ mutant in entering tomato phloem elements.}

The distribution of the viruses in the vascular tissues of tomato plants was analyzed by immunogold labeling (IGL). Ultrathin sections were prepared at $7 \mathrm{dpi}$ from cotyledons with local infection and from the first true leaf with systemic infection.

PVY-SON41 and CMV-Fny were detected in both cotyledons and true leaves (Table 2) in either single or mixed infection. In cotyledons, $C M V$-Fny $\Delta 2 b$ particles were abundant only in the mesophyll cells but were present in low numbers or absent in true-leaf phloem companion cells and immature sieve elements (Table 2; Fig. 3C). These results suggested that CMV-Fny $\Delta 2 \mathrm{~b}$ was unable to enter the phloem and invade the plant systemically. In plants mixed-infected with PVY-SON41, CMV-Fny $\Delta 2 \mathrm{~b}$ also was detected in companion cells and immature sieve elements, indicating a complementation by PVY-SON41 homologous functions necessary for CMV-Fny $\Delta 2 \mathrm{~b}$ long-distance movement (Table 2; Fig. 3D). Further IGL observations showed that, in single-infected plants, the CMV mutant was confined mostly to the bundle sheath (Fig. 4B), apparently unable to reach internal cells of phloem tissue.

Interestingly, PVY-SON41 and CMV-Fny $\Delta 2 \mathrm{~b}$ were found consistently in the same true-leaf phloem companion cell of plants with mixed infection, whereas the Potyvirus sp. was not detected together with CMV-Fny in the same companion cell (data not shown). These results parallel those obtained with tomato protoplasts in which an inhibitory effect of CMV-Fny $2 \mathrm{~b}$ protein was demonstrated, suggesting a bias of CMV-Fny against ingress or replication of PVY-SON41 in the same cell of the vascular tissue.

\section{Effects of temperature \\ on CMV-Fny $\Delta 2 \mathrm{~b}$ movement in tomato plants.}

Our results showed that the CMV-Fny $\Delta 2 \mathrm{~b}$ mutant could not move systemically in tomato from the site of infection to the newly developed vegetation as a consequence of its poor ability to enter sieve elements of the vascular system. The CMVFny $\Delta 2 \mathrm{~b}$ mutant does not encode a $2 \mathrm{~b}$ protein, which plays a key role in suppressing plant-driven RNA silencing. Because it has been proposed that RNA silencing may be hyperactivated in cells that control access to the phloem (Marathe et al. 2000), we used a differential temperature-based system to investigate whether there was a correlation between the inability of CMVFny $\Delta 2 \mathrm{~b}$ to move systemically in tomato and RNA silencing. Recent studies have shown that RNA silencing is temperature-dependent, and that it is significantly enhanced at high temperatures (Szittya et al. 2003; Chellappan et al. 2005; Qu et al. 2005) and inhibited at low temperatures. Therefore, two sets of six tomato plants were challenged with CMV-Fny, CMV-Fny $\Delta 2 b$, and CMV-Fny $\Delta 2 \mathrm{~b}$ plus PVY-SON41 and were grown at either 22 or $15^{\circ} \mathrm{C}$. Dot blot hybridization analysis carried out at 10,14 , and 21 dpi on the first, second, and third true leaf, respectively, showed that the CMV-Fny $\Delta 2 \mathrm{~b}$ mutant moved systemically in plants grown at $15^{\circ} \mathrm{C}$ (Table 3 ) and in the first true leaf of only one of six plants grown at $22^{\circ} \mathrm{C}$, whereas it was able to systemically invade plants maintained at $22^{\circ} \mathrm{C}$ only in mixed infection with PVY-SON41.

Table 2. Frequency of immunogold labeling of Cucumber mosaic virus (CMV)-Fny, CMV-Fny $\Delta 2 \mathrm{~b}$, and Potato virus $Y$ (PVY)-SON41 in single and mixed infections detected in cotyledons and first true leaf of tomato plants at 7 days postinoculation $(\mathrm{dpi})^{\mathrm{x}}$

\begin{tabular}{|c|c|c|c|c|c|}
\hline Inoculum & CMV-Fny $\Delta 2 b^{y}$ & $\begin{array}{l}\text { PVY-SON41 + } \\
\text { CMV-Fny } \Delta 2 b^{y}\end{array}$ & CMV-Fny ${ }^{\mathbf{y}}$ & $\begin{array}{l}\text { PVY-SON41 + } \\
\text { CMV-Fny } \Delta 2 b^{z}\end{array}$ & PVY-SON41 ${ }^{z}$ \\
\hline \multicolumn{6}{|l|}{ Cotyledon tissue } \\
\hline Upper epidermis & + & - & ++ & + & + \\
\hline Palisade & +++ & ++ & ++++ & ++ & ++ \\
\hline Companion cells & $-1+$ & +++ & ++++ & +++ & ++ \\
\hline Sieve elements & - & +++ & +++ & +++ & ++ \\
\hline Xylem parenchyma cells & +++ & ++++ & ++++ & ++++ & +++ \\
\hline Spongy mesophyll & +++ & ++ & ++++ & ++ & ++ \\
\hline Lower epidermis & + & + & + & + & + \\
\hline \multicolumn{6}{|l|}{ Leaf tissue } \\
\hline Upper epidermis & - & - & ++++ & +++ & +++ \\
\hline Palisade & - & ++ & ++++ & ++++ & ++++ \\
\hline Companion cells & - & ++ & ++++ & +++ & +++ \\
\hline Sieve elements & - & +++ & ++++ & ++++ & +++ \\
\hline Xylem parenchyma cells & - & ++ & ++++ & +++ & +++ \\
\hline Spongy mesophyll & - & ++ & ++++ & ++ & ++ \\
\hline Lower epidermis & - & + & ++++ & +++ & +++ \\
\hline
\end{tabular}

${ }^{\mathrm{x}}$ Symbols: $+=1$ to $10,++=11$ to $30,+++=31$ to 50 , and $++++=51$ to 70 immunogold-labeled particles per unit area (approximately $\left.0.15 \mathrm{~mm}^{2}\right)$ after background (average of 4 to 8 particles) subtraction; - = background immunogold labeling. Isolated gold particles were considered as background.

${ }^{y}$ Anti CMV antisera used.

${ }^{\mathrm{z}}$ Anti PVY antisera used. 
As a further approach, we examined the accumulation of small-interfering RNAs (siRNAs) in single and mixed infection at 28 dpi. RNA blot analysis (Fig. 5) demonstrated that there was a positive correlation between the RNA accumulation levels of CMV-Fny and CMV-LS with the corresponding siRNAs. A differential effect of the two CMV strains was observed on the accumulation of PVY-SON41-specific siRNAs because they were slightly more abundant with CMV-LS than with CMV-Fny and there was also more PVY-SON41 RNA in mixed infection with CMV-LS than with CMV-Fny. The low abundance of PVY-SON41-specific siRNA in mixed infection seems proportional to the reduced accumulation level of PVYSON41 RNA and confirms the inhibitory effect of CMV against the Potyvirus sp. On the other hand, it was not surprising that the presence of a fully functional CMV2b did not suppress siRNA accumulation, as also was observed in protoplasts (Qi et al. 2004).

Fully functional CMV $2 \mathrm{~b}$ protein and the overlapping region between $2 a$ and $2 b$ proteins are both necessary for CMV-induced symptom severity in tomato.

The experimental approach and the results reported previously provided evidence that the CMV $2 \mathrm{~b}$ protein is involved in the exacerbation of symptoms and in the systemic invasion of tomato plants, probably through the suppression of RNA silencing. Using seven other CMV-Fny 2b mutants (Lewsey et al. 2009), we investigated the importance of specific domains within the $2 b$ protein, as well as their interplay with PVYSON41 for symptom induction, plus virus movement and accumulation in tomato tissues. To determine the role of the overlapping C-terminal $2 \mathrm{a}$ protein sequence in these interactions, we also used the CMV-Fny2a776 mutant (Du et al. 2008 ), in which the $2 b$ protein was unaltered in sequence and translated, whereas the $2 \mathrm{a} / 2 \mathrm{~b}$ overlapping region of the $\mathrm{CMV}$ Fny 2 a protein was truncated.

All of the CMV $2 b$ mutants were inoculated alone or in mixed infection with PVY-SON41. The phenotypes observed in singly infected plants were essentially the same among the tested $2 \mathrm{~b}$ mutants, all of which showed very mild symptoms with no evident alteration of whole-plant morphology. In comparison with the severely diseased plants infected by CMVFny, those infected with the CMV-Fny2a776 mutant developed only moderate blistering of leaflet blades.

All these phenotypes were aggravated in mixed infections with PVY-SON41 without inducing organ malformations or marked growth reduction. Northern blot analyses at 14 dpi on
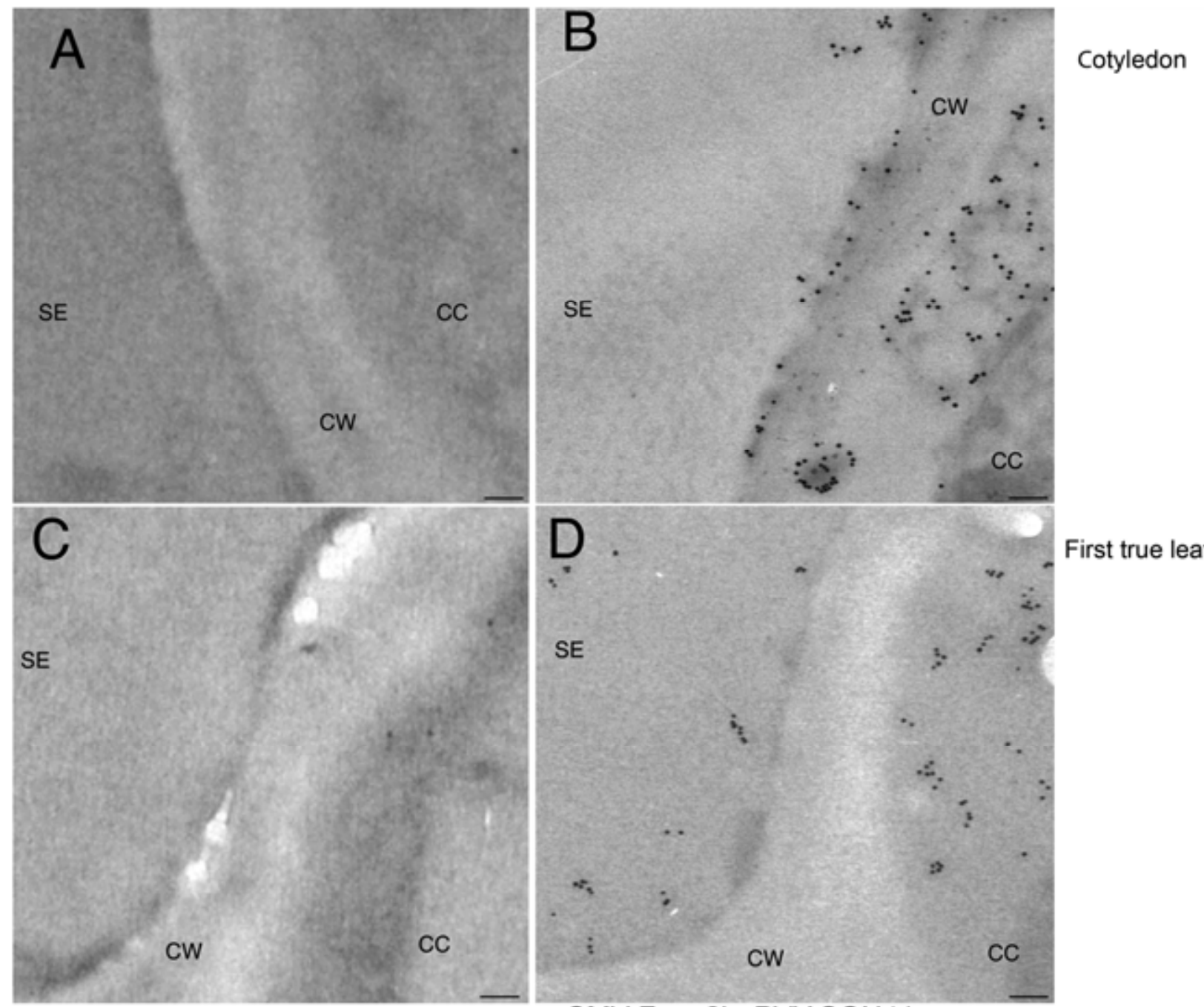

First true leaf

CMV-Fny $\Delta 2 b$

CMV-Fny $\Delta 2 b+P V Y-S O N 41$

Fig. 3. In situ localization of Cucumber mosaic virus (CMV)-Fny $\Delta 2 \mathrm{~b}$ particles by immunogold labeling (IGL) in both the cotyledon and the first true leaf tissues of tomato plants at 7 days postinoculation infected by $\mathbf{A}$ and $\mathbf{C}, \mathrm{CMV}-\mathrm{Fny} \Delta 2 \mathrm{~b}$ alone and $\mathbf{B}$ and $\mathbf{D}$, in mixed infection with Potato virus $Y$ (PVY)SON41. The CMV $2 \mathrm{~b}$ mutant virus is able to enter the plant phloem only in mixed infection with PVY-SON41. CC $=$ companion cells, $\mathrm{CW}=$ cell wall, $\mathrm{SE}=$ sieve element, and bars $=7.5 \mathrm{~mm}$ or $200 \mathrm{~nm}$. 
the first three true leaves showed that all $2 \mathrm{~b}$ mutants were able to replicate and to invade tomato plants systemically and that, in mixed infection with PVY-SON41, the accumulation levels of RNA of each $2 b$ mutant were at least three times higher than those observed in single-infected plants (Fig. 6 and data not shown). These results demonstrated that, in comparison with wild-type CMV-Fny, any of the tested changes in the $2 \mathrm{~b}$ protein as well as in the overlapping region between $2 a$ and $2 b$ proteins attenuated the symptom expression, whereas no differential effect was seen among the various $2 b$ mutants. Thus, the $\mathrm{C}$-terminus of the $2 \mathrm{a}$ protein also seems to be involved in the severe symptom induction by CMV-Fny in tomato.

On the other hand, the functions altered by the mutations introduced in the CMV $2 \mathrm{~b}$ protein as well as in the $2 \mathrm{a} / 2 \mathrm{~b}$ protein overlapping region were complemented by PVY-SON41. These observations were congruent with those reported in a recent study (Cillo et al. 2009), where it was demonstrated that i) the development of severe disease phenotype induced by CMV-Fny infection in tomato was associated with high RNA accumulation level and ii) the two traits relied both on a fully functional $2 \mathrm{~b}$ protein and on the $\mathrm{C}$-terminus of the $2 \mathrm{a}$ protein of this CMV strain.

\section{CMV-satRNA mitigates the inhibitory effects of CMV on PVY.}

In two previous articles (Cillo et al. 2004, 2007), it was shown that, when the CMV-Fny inoculum contained the ameliorative Tfn-satellite (sat)RNA variant, the genomic RNAs were reduced to barely detectable levels and the infection was symptomless. The condition under which a correlation was observed between latent infection and a sharp reduction of viral RNA accumulation was referred to as latent infection and downregulation (LI-DR) (Cillo et al. 2007). In this study, we wanted to determine whether the LI-DR condition in tomato could be affected by mixed infection with PVY-SON41. Plants infected by CMV plus Tfn-satRNA were substantially asymptomatic as were plants infected by the two viruses plus TfnsatRNA. Control plants infected by CMV-Fny, PVY-SON41, or a mixture of the two showed the symptoms already described. The infection with CMV-Fny plus Tfn-satRNA showed a suppression of CMV RNA accumulation, and this was not affected by the presence of PVY-SON41 (Fig. 7, compare lanes FTfn and PFTfn), whereas the accumulation of PVY-SON41 RNA increased (Fig. 7, compare lanes PF and PFTfn). The accumulation level of Tfn-satRNA level remained substantially unchanged regardless of the presence of the Potyvirus sp. (Fig. 7, compare lanes FTfn and PFTfn). Although a direct effect of Tfn-satRNA on PVY-SON41 replication could be not ruled out, it seems very likely that, in tomato plants with mixed infection, Tfn-satRNA indirectly aided the accumulation of PVYSON41 by the downregulation of its helper virus, thus attenuating its antagonistic effect to the Potyvirus sp.

\section{DISCUSSION}

Interaction between PVY and CMV was examined in tomato using PVY-SON41 and two strains of CMV. Interestingly, an apparently unaltered pattern of CMV RNA accumulation in the mixed-infected plants was observed at $60 \mathrm{dpi}$ when the titer of the virus was expected to decrease (D. Gallitelli and F. Cillo, unpublished observations) (Rochow 1972; Kaper and Tousignant 1984; Zeng et al. 2007). In these plants, the two CMV strains

Table 3. Effect of growing temperature on the infection of tomato plants with different inocula ${ }^{y}$

\begin{tabular}{|c|c|c|c|c|c|c|}
\hline \multirow[b]{2}{*}{ Inoculum $^{\mathrm{Z}}$} & \multicolumn{2}{|c|}{ CMV-Fny } & \multicolumn{2}{|c|}{ CMV-Fny $\Delta 2 b$} & \multicolumn{2}{|c|}{$\begin{array}{c}\text { CMV-Fny } \Delta 2 b+ \\
\text { PVY-SON41 }\end{array}$} \\
\hline & $15^{\circ} \mathrm{C}$ & $22^{\circ} \mathrm{C}$ & $15^{\circ} \mathrm{C}$ & $22^{\circ} \mathrm{C}$ & $15^{\circ} \mathrm{C}$ & $22^{\circ} \mathrm{C}$ \\
\hline $10 \mathrm{dpi}$ & $6 / 6$ & $6 / 6$ & $2 / 6$ & $1 / 6$ & $2 / 6$ & $2 / 6$ \\
\hline $14 \mathrm{dpi}$ & $6 / 6$ & $6 / 6$ & $3 / 6$ & $0 / 6$ & $3 / 6$ & $6 / 6$ \\
\hline $21 \mathrm{dpi}$ & $6 / 6$ & $6 / 6$ & $6 / 6$ & $0 / 6$ & $5 / 6$ & $6 / 6$ \\
\hline
\end{tabular}

${ }^{\mathrm{y}}$ Number of plants infected/number of plants inoculated at each temperature. Infected plants were identified by dot blot hybridization with a Cucumber mosaic virus (CMV)-specific probe. $\mathrm{PVY}=$ Potato virus $Y$.

${ }^{\mathrm{z}}$ Inoculum at days postinoculation (dpi).

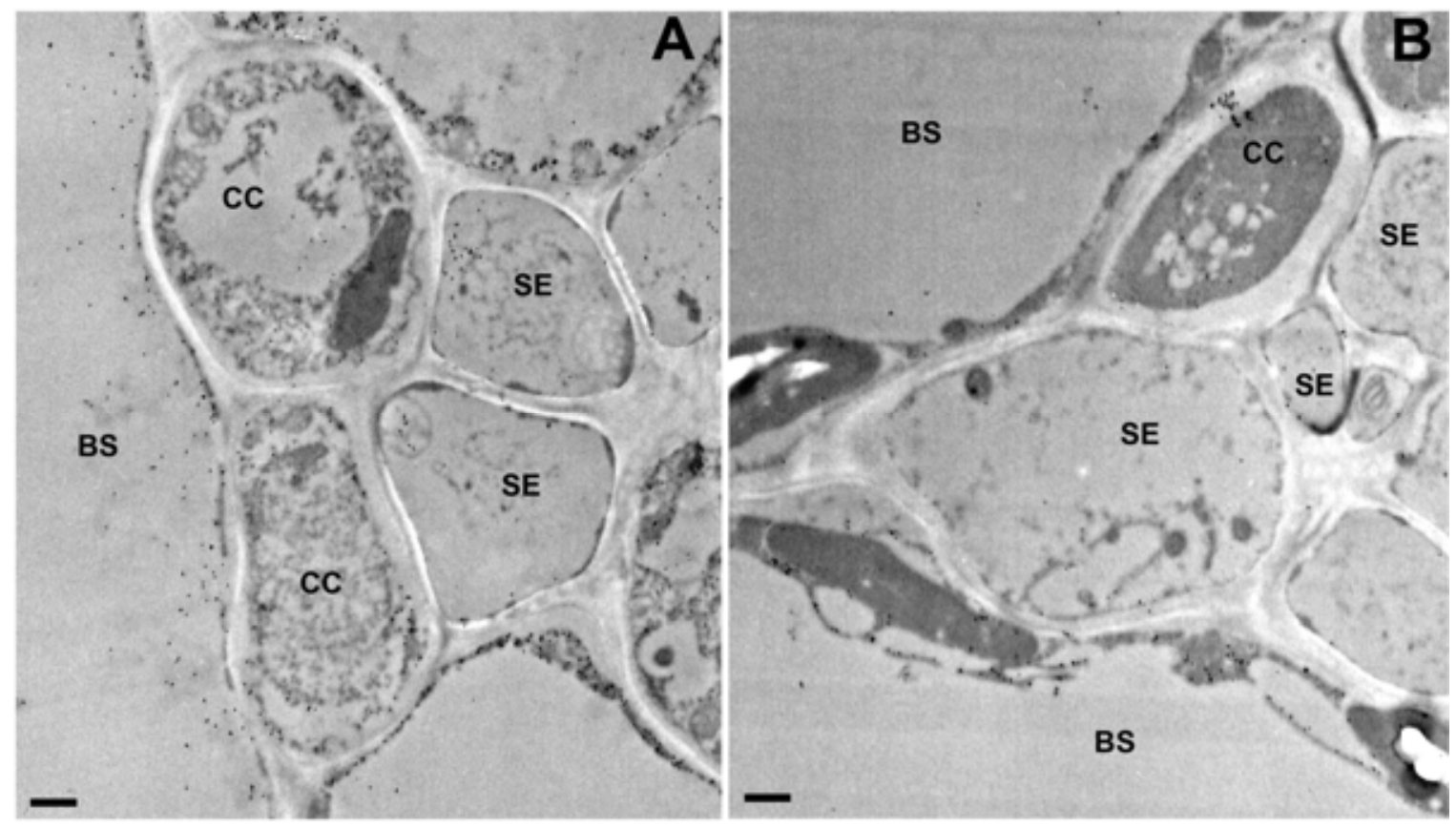

Fig. 4. A, In situ localization of Cucumber mosaic virus (CMV)-Fny particles by immunogold labeling (IGL) in cotyledon tissues of tomato plants at 7 days postinoculation (dpi). Bar $=500 \mathrm{~nm}$. B, In situ localization of CMV-Fny $\Delta 2 \mathrm{~b}$ particles by IGL in cotyledon tissues of tomato plants at 7 dpi. CMV mutant was confined mostly to the bundle sheath and was apparently unable to reach internal cells of phloem tissue. Bar $=500 \mathrm{~nm}$. BS $=$ bundle sheath, SE $=$ sieve elements $(\mathrm{SE})$, and $\mathrm{CC}=$ companion cells. 
and PVY-SON41 also were more uniformly distributed throughout the host tissues. This was consistent with the results of Zeng and associates (2007), who found that mixed infection of CMV and ZYMV in cucumber and bottle gourd stimulated early-stage replication of CMV RNAs and delayed the decline of their accumulation levels. A similar behavior was also observed in celery with mixed infection of CMV and Potyvirus sp. Celery mosaic virus. In this host, the decrease of CMV titer was delayed by 1 week compared with plants infected by CMV alone (Zitter 1970). The overall level of PVY-SON41 RNA was

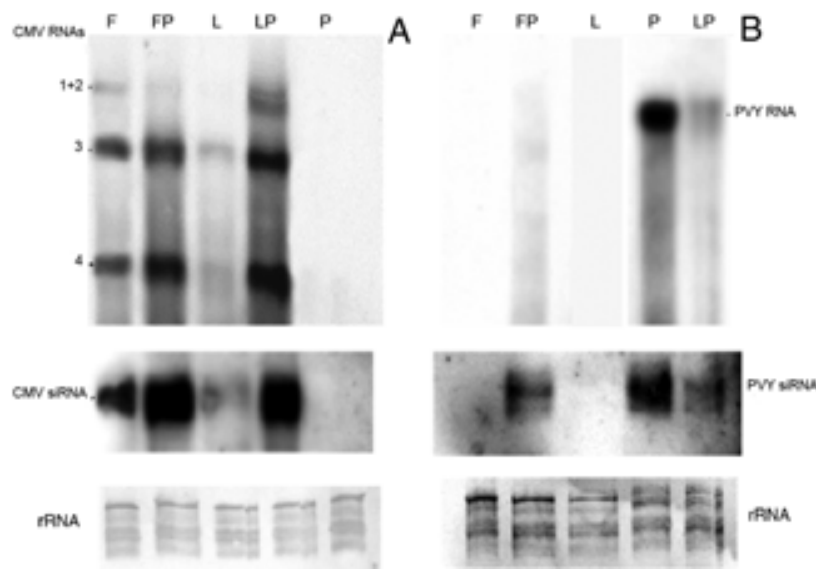

Fig. 5. Northern blot analysis of viral RNAs (genomic and small interfering RNAs [siRNAs]). RNA preparations were extracted at 28 days postinoculation from the third true tomato leaf in plants infected by Cucumber mosaic virus (CMV)-Fny (F), CMV-LS (L), and Potato virus Y (PVY)SON41 (P) alone and in different inoculum combinations. There is a positive correlation between the amount of viral RNA and the accumulation level of the respective siRNAs. The low abundance of PVY-specific siRNA in plants double-infected by CMV-Fny or CMV-LS seems proportional to the reduced accumulation level of PVY-SON41 RNA and confirms the inhibitory effect of CMV against PVY-SON41. A and B, Hybridized with CMV- and PVY-specific riboprobes, respectively. Methylene blue staining of rRNA after blotting on membrane was used to confirm equal loading of RNA in all the tracks. lower in plants mixed-infected by CMV-Fny up to 28 dpi than in plants infected by the Potyvirus sp. alone. In this respect, the results with tomato plants parallel those with tobacco (Palukaitis and Kaplan 1997), where the presence of CMV allowed a more

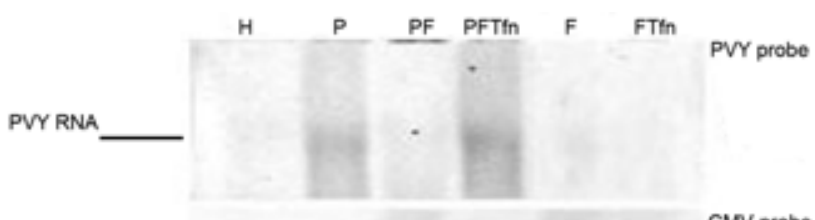

CMV probe

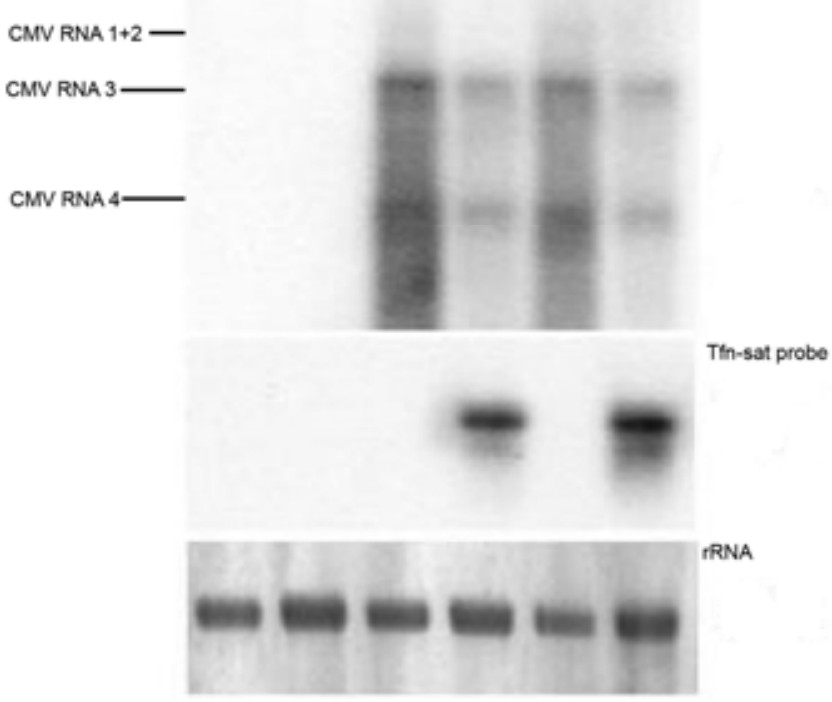

Fig. 7. Northern blot analysis of RNA preparations extracted from UC82 tomato plants at 28 days postinoculation with Cucumber mosaic virus (CMV)-Fny (F), Potato virus $Y$ (PVY)-SON41 (P), CMV-Fny plus Tfnsatellite (sat)RNA (FTfn), PVY-SON41 plus CMV-Fny (PF), and PVYSON41 plus CMV-Fny plus Tfn-satRNA (PFTfn). $\mathrm{H}=$ RNA preparations extracted from mock-inoculated tomato plants. Blots were hybridized with digoxigenin-labeled riboprobes for PVY, CMV, and satRNA. Methylene blue staining of rRNA after blotting on membrane was used to confirm equal loading in all the tracks.

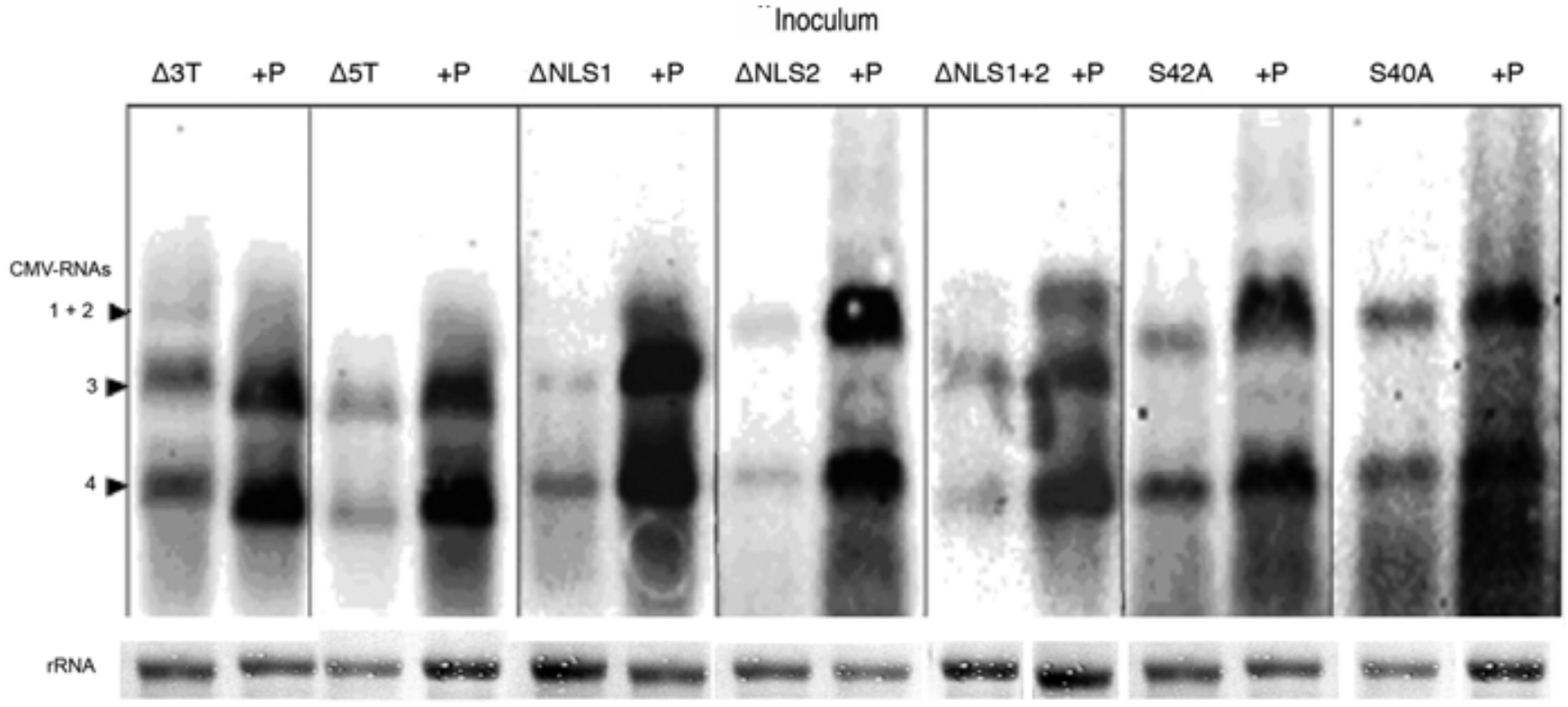

Fig. 6. Northern blot analysis at 14 days postinoculation on the third true tomato leaf showing accumulation of RNAs of Cucumber mosaic virus (CMV)-Fny mutants $\Delta 3 \mathrm{~T}=\mathrm{CMV}-\mathrm{Fny}-2 \mathrm{~b} \Delta 3 \mathrm{~T}, \Delta 5 \mathrm{~T}=\mathrm{CMV}-\mathrm{Fny}-2 \mathrm{~b} \Delta 5 \mathrm{~T}, \Delta \mathrm{NLS} 1=\mathrm{CMV}-\mathrm{Fny}-2 \mathrm{~b} \Delta \mathrm{NLS} 1, \Delta \mathrm{NLS} 2=\mathrm{CMV}-\mathrm{Fny}-2 \mathrm{~b} \Delta \mathrm{NLS} 2, \Delta \mathrm{NLS} 1+2=\mathrm{CMV}-\mathrm{Fny}-$ $2 \mathrm{~b} \Delta \mathrm{NLS} 1+2, \mathrm{~S} 40 \mathrm{~A}=\mathrm{CMV}-\mathrm{Fny}-2 \mathrm{bS} 40 \mathrm{~A}$, and S42A = CMV-Fny-2bS42A inoculated alone or in mixed infection with Potato virus $Y$ (PVY)-SON41 (indicated as $+\mathrm{P}$ ). Blot was hybridized with a CMV-specific riboprobe. Methylene blue staining of rRNA after blotting on membrane was used to confirm equal loading of RNA in all the tracks. 
uniform systemic spread of PVY in all tissues but did not enhance its replication; rather, this was downregulated compared with single-infected plants. Reduction of ZYMV accumulation in mixed infection with CMV also has been reported in cucumber plants (Poolpol and Inouye 1986).

To establish whether the synergistic effect on CMV increased abundance and systemic movement was determined by a larger number of infected cells, by an increased RNA accumulation level per cell, or by both, we carried out experiments in tomato protoplasts. In mixed-infected cells, the replication of CMVFny was high while that of CMV-Fny $\Delta 2 b$ remained at very low levels in either single or mixed infection. This demonstrated that functions absent in the CMV mutant could not be compensated by PVY-SON41. However, this behavior seems to be host dependent because, in tobacco protoplasts, the absence of the $2 \mathrm{~b}$ protein delayed but did not inhibit the replication of the CMV-Fny $\Delta 2$ b mutant (Soards et al. 2002). The replication of PVY-SON41 was depressed in mixed infection with CMV-Fny and this was due to the $2 \mathrm{~b}$ protein, because protoplasts infected by PVY-SON41 and CMV-Fny $\Delta 2 \mathrm{~b}$ did not show such an inhibitory effect; rather, the CMV mutant favored the accumulation of the Potyvirus sp.

In conclusion, it is likely that the high accumulation level of CMV-Fny RNA observed between 7 and 60 dpi in tomato plants with mixed infection was the result of both an increased number of infected cells and an increased abundance of viral RNA per cell. Concomitantly, PVY-SON41 replication was downregulated at the single-cell level and this also may explain why its RNA accumulated at lower levels in the systemically infected tissues, reaching a uniform distribution within tomato tissues only at late infection stages. Therefore, we can hypothesize that the cells accounting for the PVY-SON41 accumulation were mostly those not infected by CMV or those in which CMV infection was established after that of PVY-SON41. This hypothesis is supported by the observation that, in invading the plant systemically, the two viruses seem unable to establish replication in the same phloem cell. The molecular basis for such restricted competence of PVY-SON41 for phloem cells infected by CMV-Fny has not been clearly elucidated but there is indirect evidence that the $2 \mathrm{~b}$ protein of CMV could accounts for this, because PVY-SON41 was detected in the same phloem cells infected by CMV-Fny $\Delta 2 \mathrm{~b}$. In conclusion, we propose that, at early infection time points, the low number of PVY-SON41-infected cells per plant could not compensate for the strong downregulation of the virus as well as the restricted phloem tissue infiltration driven by CMV-Fny, and the overall accumulation of PVY-SON41 RNA was reduced. At later stages of infection, an equilibrium probably was reached so that both viruses obtained reciprocal advantages.

Unlike the situation in tomato, the synergistic interaction between CMV and ZYMV in susceptible cucurbit cultivars produced an increase in the number of infected cells rather than an increase in CMV RNA accumulation level in single cells (Poolpol and Inouye 1986; Palukaitis and Garcia-Arenal 2003). Similar to tomato, an increase in the accumulation of CMV-Fny RNA but not of ZYMV RNA has been reported by Wang and associates (2004) in cucumber protoplasts, although the replication of ZYMV was not inhibited but remained at the same level. The emerging picture seems to suggest that, in tomato protoplasts, CMV-Fny uses some functions coded for by the other virus more profitably than PVY-SON41. The action of HC-Pro and 2b SRS proteins, working concomitantly in the same infected cell, could provide one possible explanation. The CMV $2 b$ protein is particularly active in suppressing silencing in young, nonsilenced cells as well as in all developing plant shoots, while being unable to suppress silencing in already silenced older cells (Brigneti et al. 1998). By contrast,
PVY HC-Pro protein acts as an SRS regardless of the plant cell or tissue types and whether or not they were silenced previously (Brigneti et al. 1998). Because protoplasts do not have meristematic activity and are more similar to older plant cells, it is very likely that, at the single-cell level, HC-Pro is an SRS more active than the $2 \mathrm{~b}$ protein. Extensive analyses have shown that HC-Pro and $2 \mathrm{~b}$ proteins represent two distinct groups of SRS (Li and Ding 2001, 2006; Roth et al. 2004; Diaz-Pendon et al. 2007). HC-Pro is a cytoplasmic protein that prevents the assembly of siRNAs into the active RNA-induced silencing complex by binding to and sequestering duplex siRNAs (Lakatos et al. 2006; Merai et al. 2006). By contrast, CMV 2b, which accumulates in the nucleus and cytoplasm of plant cells, is an inhibitor of intercellular silencing spread (Guo and Ding 2002). Their distinct role as SRS could explain why, at the single-cell level, HC-Pro enhances replication of CMV-Fny, whereas PVY-SON41 does not receive any beneficiary effect from the presence of the $2 b$ protein. The work of Qi and associates (2004) has shown that both the CMV 2b and the Tobacco etch virus (TEV) HC-Pro protein also are very potent SRS in single cells, although with different mechanisms. In particular, it has been proposed that $2 \mathrm{~b}$ protein also could have a role in enhancing translation by suppressing translational repression caused by siRNA, and this could explain why CMV-Fny $\Delta 2 \mathrm{~b}$ replicates poorly in protoplasts. This property of the $2 \mathrm{~b}$ protein has been demonstrated using a heterologous protein such as the green fluorescent protein (Qi et al. 2004) but it cannot be excluded that $2 \mathrm{~b}$ protein has a preferential role in enhancing translation of CMV proteins during an authentic virus infection over heterologous proteins. In our model, this could perturb the overall replication and accumulation kinetics of PVY by outcompeting it in translational efficiency. However, this issue needs further study. This single-cell model also could provide some explanations for the advantage that CMV obtains at the expense of PVY-SON41 in colonizing the whole tomato plant.

To further examine the possible mechanism or mechanisms underlying some of the results shown in this work, we used the CMV-Fny $\Delta 2 \mathrm{~b}$ mutant, because it was unable to move systemically in tomato. Plant resistance to viral infections expressed in the form of restricted systemic movement of the virus has been described previously for various virus-host systems. In most cases, the resistance appears to involve the inability of the pathogen to enter or exit the phloem, and specific cell types or locations of tissues associated with blockage of virus movement have been reported (Nelson and van Bel 1998; Hull 2002). In some cases, mixed infections by two viruses have been shown to overcome barriers to either the cell-to-cell or the long-distance movement of one of the viruses (Atabekov and Taliansky 1990; Nelson and van Bel 1998; Hull 2002). In our study, IGL provided direct evidence that the CMV-Fny $\Delta 2 \mathrm{~b}$ mutant was blocked at the level of the bundle sheath of the tomato phloem, and that the function needed for invading the phloem was complemented by PVY-SON41. However, the presence of PVY-SON41 was not necessary for CMV-Fny $\Delta 2 b$ systemic movement in plants grown at $15^{\circ} \mathrm{C}$. It has been proposed that RNA silencing is inactive at low temperature (Szittya et al. 2003); therefore, we can speculate that RNA silencing could be the mechanism responsible for blocking the CMVFny $\Delta 2 \mathrm{~b}$ mutant at the bundle sheath boundary level. The notion that viruses can move within plant tissues by blocking the systemic signal of RNA silencing (Vance and Vaucheret 2001; Voinnet 2001; Baulcombe 2002) supports our hypothesis. Given that the CMV 2b protein autonomously enters and probably translocates through the phloem tissues (Guo and Ding 2002), it is likely that it suppresses the mobile signals of silencing against $\mathrm{CMV}$ otherwise blocking the CMV-Fny $\Delta 2 \mathrm{~b}$ 
mutant at the bundle sheath level. In double-infected plants, this function is very likely supplied by the PVY HC-Pro SRS.

Finally, the presence of an ameliorative agent of CMV infection, like the Tfn-satRNA, did perturb the interplay between CMV and PVY-SON41 in tomato, acting as a dominant factor in the interaction. In two previous articles, it was shown that the accumulation of genomic RNAs of CMV-Fny in this host was reduced to barely detectable levels and the infection was symptomless when the inoculum contained the Tfn-satRNA (Cillo et al. 2004, 2007). In downregulating CMV replication in tomato, Tfn-satRNA indirectly i) mitigated the inhibition against PVY-SON41, in that the virus accumulated to high levels; ii) abolished disease symptoms; and iii) provided indirect evidence that exacerbation of disease symptoms in doubleinfected plants was very likely attributable to pathogenicity determinants encoded by CMV. These results do not seem congruent with those reported in other instances by using different hosts, CMV satellites, and Potyvirus spp., thus suggesting that the overall phenotype observed in this study is peculiar to tomato. For example, Wang and associates (2002) found that ZYMV stimulated both CMV-satRNA and CMV RNA accumulation in cucurbits, whereas Pruss and associates (1997), who used whole transgenic tobacco plants expressing the P1/HC-Pro of TEV, found that the HC-Pro increased CMV levels but suppressed those of the CMV-satRNA.

We have shown that the analysis of the combined action of CMV and PVY in tomato resulted in a number of striking findings, some of which were peculiar to this host. From an ecological and epidemiological perspective, it is relevant that both viruses accumulated to an evidently increased titer and with a very good distribution up to 60 dpi compared with single infections, thus being available for aphid transmission in any part of the plant where aphid populations feed. It is also relevant that, in mixed infection in tomato, CMV-satRNA reduces the accumulation of its helper virus, causing an enhancement of the potyviral counterpart. This could introduce a bias against CMV for aphid transmission while it increases the probabilities of transmission for PVY-SON41. A decrease in the efficiency of CMV transmission from CMV-satRNA-infected tomato plants has been documented previously (Escriu et al. 2000).

\section{MATERIALS AND METHODS}

\section{Plants and viruses.}

Tomato (S. lycopersicum cv. UC82) seedlings were inoculated by rubbing Celite-dusted cotyledons with sap obtained from $1 \mathrm{~g}$ of infected tomato leaf tissues after 12 to 15 days of systemic infection ground in 20 volumes (wt/vol) of $100 \mathrm{mM}$ phosphate $\left(\mathrm{Na}_{2}-\mathrm{K}\right)$ buffer, $\mathrm{pH}$ 7.2. For mixed infections, an interval of 3 days was used between the first (PVY) and the second (CMV) inoculation. Controls were either plants mock inoculated with buffer alone or, in the case of mixed infections, plants in which the second inoculation was substituted with a mock inoculation. After inoculation, all the plants were grown in glasshouse at $22^{\circ} \mathrm{C}\left( \pm 2^{\circ} \mathrm{C}\right)$ with a 16 -h photoperiod and were observed for disease symptoms every week up to 2 months.

The two CMV strains, CMV-Fny (subgroup IA) (Owen and Palukaitis 1988) and CMV-LS (subgroup II) (Wahyuni et al. 1992), were maintained on UC82 tomato and purified from 12day-old systemically infected leaves according to the procedure of Lot and associates (1972). The strain PVY-SON41, kindly provided by B. Moury (INRA, Montfavet, France), was maintained in Nicotiana tabacum cv. Samsun and purified from systemically infected leaves harvested 2 weeks after inoculation, according to the method of Thompson and associates (1988).
Other CMV inocula used were CMV-Fny $\Delta 2 b$, transcribed from plasmid pFny209/M3, in which the sequences encoding the $2 \mathrm{~b}$ protein (nucleotides 2,419 to 2,713 ) have been deleted by site-directed mutagenesis (Ryabov et al. 2001); CMV-Fny2b $\Delta$ NLS1, CMV-Fny-2b $\Delta N L S 2$, and CMV-Fny-2b $\Delta L N S 1+2$, in which the coding region for nuclear localization signal (NLS) 1, 2, or both was deleted within the 2b protein (Lewsey et al. 2009); CMV-Fny-2bS40A and CMV-Fny-2bS42A, in which serine residues 40 and 42 of the $2 \mathrm{~b}$ protein were replaced by alanine residues (Lewsey et al. 2009); CMV-Fny$2 \mathrm{~b} \Delta 3 \mathrm{~T}$, in which the 3 '-terminal RNA sequence of the $2 \mathrm{~b}$ open reading frame (ORF), corresponding to the $\mathrm{C}$-terminal 16 amino acids of the $2 \mathrm{~b}$ protein, was truncated (Lewsey et al. 2009); CMV-Fny-2b $\Delta 5 \mathrm{~T}$, in which the 5'-terminal RNA sequence of the $2 \mathrm{~b} \mathrm{ORF}$, corresponding to the N-terminal 17 amino acids of the $2 \mathrm{~b}$ protein, was deleted (Lewsey et al. 2009); and CMV-Fny2a776, in which the two termination codons that were introduced by changing nucleotides AAT at 2,415 to 2,417 to TGA and nucleotides $\mathrm{G}$ to $\mathrm{T}$ at 2,520 rendered the $2 \mathrm{a} / 2 \mathrm{~b}$ overlapping region of the $2 \mathrm{a}$ protein noncoding ( $\mathrm{Du}$ et al. 2008). All the CMV mutants were kindly supplied by M. Lewsey and J. Carr, (Department of Plant Sciences, University of Cambridge, Cambridge, U.K.) All of the mutants were transcribed from their respective plasmids by the mMESSAGE mMACHINE Kit (Ambion, Austin, TX, U.S.A.) following the manufacturer's protocol and the resulting transcripts were inoculated onto tomato plants as described above.

CMV-Fny plus Tfn-satRNA (Cillo et al. 2007) was used to evaluate mixed infections in the presence of a CMV-satRNA.

\section{Preparation and inoculation} of tomato mesophyll protoplasts.

Seed of tomato cv. UC82 were germinated in a growth chamber at $23^{\circ} \mathrm{C}$ and 55 to $60 \%$ relative humidity under white fluorescent light with a photoperiod of $14 \mathrm{~h}$ of light and $10 \mathrm{~h}$ of darkness. The youngest fully expanded leaves of 28- to 30-day-old plants were harvested and utilized for protoplast isolation according to the method described by Paciolla and associates (2004) with some modifications. Briefly, tomato leaf segments were incubated for $15 \mathrm{~min}$ at room temperature in preplasmolysis buffer consisting of $25 \mathrm{mM}$ Tris-morpholino-ethane-sulphonic acid, $\mathrm{pH} 5.5$, containing $0.6 \mathrm{M}$ sorbitol, $0.5 \%$ (wt/vol) bovine serum albumin, and $0.5 \%$ (wt/vol) $\mathrm{CaCl}_{2}$. After incubation, the buffer was replaced by a fresh solution supplemented with $1 \%$ (wt/vol) Cellulase Onozuka R-10 and $0.25 \%$ (wt/vol) Macerozyme R-10 (Duchefa, Haarlem, The Netherlands). The digestion was left to proceed for 16 to $18 \mathrm{~h}$ at room temperature in the dark. Released protoplasts were filtered through Miracloth (Calbiochem, La Jolla, CA, U.S.A.) and collected by centrifugation at $680 \mathrm{rpm}$ for $8 \mathrm{~min}$. The pellet was washed four times with preplasmolysis buffer adjusted to $\mathrm{pH} 7.4$ and resuspended to the final concentration of $7.5 \times$ $10^{5}$ to $1 \times 10^{6}$ protoplast $\mathrm{ml}^{-1}$. After isolation, protoplast viability was approximately $85 \%$. Aliquots of the protoplast suspension $(1 \mathrm{ml}$ each) were pelleted and supplemented, sequentially, with $20 \mu \mathrm{l}$ of purified virus suspension $(2 \mu \mathrm{g}$ of virus for single inoculations and $2 \mu \mathrm{g}$ of each virus in double inoculations), $200 \mu \mathrm{l}$ of $10 \%$ (wt/vol) mannitol, $200 \mu \mathrm{l}$ of $40 \%$ (wt/vol) PEG 4000, and $10 \mathrm{mM} \mathrm{CaCl}$. Protoplasts were incubated at room temperature for $5 \mathrm{~min}$ and after the addition of 1 $\mathrm{ml}$ of $10 \%$ mannitol kept on ice for $15 \mathrm{~min}$. Subsequently, the protoplasts were lysed directly for RNA extraction $(0 \mathrm{~h}$ of incubation) or maintained for $24 \mathrm{~h}$ at room temperature in $2 \mathrm{ml}$ of Takebe medium (Takebe et al. 1968) before RNA extraction with Tri-Reagent (Invitrogen, Paisley, U.K.) according to the manufacturer's instructions. Experiments were repeated in triplicate. 


\section{Real-time PCR detection and quantification} of viral RNA from tomato protoplasts.

RNA preparations from protoplast samples were subjected to on-column DNase digestion (RNase-free DNase set and RNeasy Mini Kit; Qiagen GmbH, Germany) following the manufacturer's instructions, denatured at $95^{\circ} \mathrm{C}$ for $3 \mathrm{~min}$, and reverse-transcribed in the presence of random hexamers (HighCapacity Reverse Transcription Reagents; Applied Biosystems International, Foster City, CA, U.S.A.) in $20 \mu$ of total reaction volume, containing $1 \mu \mathrm{g}$ of total RNA, and incubated at $25^{\circ} \mathrm{C}$ for $10 \mathrm{~min}, 42^{\circ} \mathrm{C}$ for $2 \mathrm{~h}$, and $85^{\circ} \mathrm{C}$ for $1 \mathrm{~min}$. Primer pairs used for quantitative real-time PCR amplification were CMV-Fny RNA3 forward (5'-GAGTCGTGCTGTCCGCACA TATTTTA-3') and CMV-Fny RNA3 reverse (5'-AGAAGGAA GCAATACGACCGTGGGTTA-3'), corresponding to the region between nucleotides 61 and 333 of the CMV-Fny RNA 3 sequence (accession no. D00385); PVY HC-Pro forward (5'-AT GCGAGGGATGGTTTGAGTCGACTGGGA-3') and PVY HC-Pro reverse (5'-TTGGGCCATCTGCCATTCATGAGCT GT-3'), flanking a region between nucleotides 1,261 and 1,499 of the PVY-SON41 sequence (accession number AJ439544); and actin forward (5'-TGATGGTGTGAGTCACACTGTCC$\left.3^{\prime}\right)$; actin reverse (5'-CCTGGCAGTTTCAATCTCCTGCTC-3'), corresponding to a fragment of $226 \mathrm{bp}$ on the tomato actin mRNA (Tom51, accession no. BM956697). The fragment of the actin-coding sequence was used as endogenous reference gene.

Real-time PCR was set up in $10 \mu$ of total volume that contained Power SYBRGreen PCR master mix (Applied Biosystems), $1 \mu \mathrm{l}$ of cDNA template, and $300 \mathrm{nM}$ each of the forward and reverse primer pairs. Each cDNA sample was amplified in triplicate on a single 48-well optical plate using the StepOne Real-Time PCR system (Applied Biosystems). The cycling profile consisted of $95^{\circ} \mathrm{C}$ for $10 \mathrm{~min}$ followed by 40 cycles of $15 \mathrm{~s}$ at $95^{\circ} \mathrm{C}$ and $1 \mathrm{~min}$ at $60^{\circ} \mathrm{C}$, as recommended by the manufacturer. Immediately after the final PCR cycle, a melting curve analysis was done to determine the specificity of the reaction. Relative quantification was calculated using the comparative cycle threshold $(\mathrm{Ct})$ method $\left(\mathrm{RQ}=2^{-\Delta \Delta \mathrm{Ct}}\right.$ ) (Livak and Schmittgen 2001), in which the change in the amount of the target viral RNA was normalized in relation to the endogenous control. Validation experiments were done according to the manufacturer's instructions (Applied Biosystems) to compare the amplification efficiencies of the virus-specific and the endogenous actin mRNA primers. Statistical significance of the values was assessed by analysis of variance with $P<0.05$.

Nucleic acid extraction and analysis by blot hybridization.

Northern and tissue print blots were used to verify the virus distribution in single- and double-infected plants and to compare relative amounts of viral nucleic acids. For Northern blot analysis, total RNA was extracted from 100-mg leaf disks cut from either the inoculation leaf at $7 \mathrm{dpi}$ or from the third systemically infected leaves at 28 and $60 \mathrm{dpi}$, as described by Cillo and associates (2007). Three RNA samples of approximately $1 \mathrm{mg}$ each per inoculum combination were run through a denaturing $1.2 \%$ agarose gel and transferred to positively charged nylon membranes. For tissue print blot analysis, tomato plants at $60 \mathrm{dpi}$ were cut at various positions along the stem and leaf petioles and exposed surfaces were gently pressed onto positively charged nylon membranes wetted in 50 $\mathrm{mM} \mathrm{NaOH}$ and $2.5 \mathrm{mM}$ EDTA and dried down at room temperature before blotting. CMV- and PVY-specific riboprobes were derived from the 3 '-terminal sequences conserved in all four CMV RNAs (Gal-On et al. 1994) and from the 3'-terminal 1,800 bases of the PVY genome, respectively. Probe synthesis, hybridization procedures, and densitometric quantifica- tions of RNA blots were as described previously (Cillo et al. 2007).

For analysis of virus-derived siRNAs, low molecular weight RNA was prepared, separated in denaturing polyacrylamide gels, and transferred to nylon membranes and quantified as previously described (Cillo et al. 2004) with the only exception being that digoxigenin-labeled instead of radioactively labeled probes were used.

Preparation of tomato cotyledons and leaf tissues for IGL.

Samples collected from cotyledons and the first true leaf of four different tomato plants at $7 \mathrm{dpi}$ for each inoculum combination were fixed, embedded in acryl resin LR white, and prepared for thin sectioning and IGL essentially as described by Cillo and associates (2002). Polyclonal rabbit antisera raised against CMV and PVY were used as sources of immunoglobulin $\mathrm{G}$ (IgG). In total, 30 ultrathin sections were labeled with goat anti-rabbit IgG conjugated to $15 \mathrm{~nm}$ gold particles (Amersham Pharmacia Biotech, Buckinghamshire, U.K.), washed, stained with uranyl acetate and lead citrate, and examined with the electron microscope Philips Mod. Morgagni Tem-268.

\section{ACKNOWLEDGMENTS}

This work was supported, in part, by a grant of MURST in the framework of CEGBA, University of Bari.

\section{LITERATURE CITED}

Atabekov, J. G., and Taliansky, M. E. 1990. Expression of a plant viruscoded transport function by different viral genomes. Adv. Virus Res. 38:201-248.

Baulcombe, D. 2002. Viral suppression of systemic silencing. Trends Microbiol. 10:306-308.

Brigneti, G., Voinnet, O., Li, W. X., Ji, L. H., Ding, S. W., and Baulcombe, D. C. 1998. Viral pathogenicity determinants are suppressors of transgene silencing in Nicotiana benthamiana. EMBO (Eur. Mol. Biol. Organ.) J. 17:6739-6746.

Chellappan, P., Vanitharani, R., Ogbe, F., and Fauquet, C. M. 2005. Effect of temperature on geminivirus-induced RNA silencing in plants. Plant Physiol. 138:1828-1841.

Choi, S. K., Yoon, J. Y., Ryu, K. H., Choi, J. K., Palukaitis, P., and Park, W. M. 2002. systemic movement of a movement-deficient strain of Cucumber mosaic virus in zucchini squash is facilitated by a cucurbitinfecting potyvirus. J. Gen. Virol. 83:3173-3178.

Cillo, F., Roberts, I. M., and Palukaitis, P. 2002. In situ localization and tissue distribution of the replication-associated proteins of Cucumber mosaic virus in tobacco and cucumber. J. Virol. 76:19654-19664.

Cillo, F., Finetti-Sialer, M. M., Papanice, M. A., and Gallitelli, D. 2004. Analysis of mechanisms involved in the Cucumber mosaic virus satellite RNA-mediated transgenic resistance in tomato plants. Mol. PlantMicrobe Interact. 17:98-108.

Cillo, F., Pasciuto, M. M., De Giovanni, C., Finetti-Sialer, M. M., Ricciardi, L., and Gallitelli, D. 2007. Response of tomato and its wild relatives in the genus Solanum to Cucumber mosaic virus and satellite RNA combinations. J. Gen. Virol. 88:3166-3176.

Cillo F., Mascia, T., Pasciuto, M. M., and Gallitelli, D. 2009. Differential effects of mild and severe Cucumber mosaic virus strains in the perturbation of microRNA-regulated gene expression in tomato map to the $3^{\prime}$ sequence of RNA 2. Mol. Plant-Microbe Interact. 22:1239-1249.

Diaz-Pendon, J. A. Li, F., Li, W. X., and Ding, S. W. 2007 Suppression of antiviral silencing by Cucumber mosaic virus $2 \mathrm{~b}$ protein in Arabidopsis is associated with drastically reduced accumulation of three classes of viral small interfering RNAs. Plant Cell 19:2053-2063.

Du, Z., Chen, F., Zhao, Z., Liao, Q., Palukaitis, P., and Chen, J. 2008. The $2 \mathrm{~b}$ protein and the $\mathrm{C}$-terminus of the 2 a protein of Cucumber mosaic virus subgroup I strains both play a role in viral RNA accumulation and induction of symptoms. Virology 380:363-370.

Escriu, F., Perry, K. L., and García-Arenal F. 2000. Transmissibility of Cucumber mosaic virus by Aphis gossypii correlates with viral accumulation and is affected by the presence of its satellite RNA. Phytopathology 90:1086-1072.

Gallitelli, D. 2000. The ecology of Cucumber mosaic virus and sustainable agriculture. Virus Res. 71:9-21. 
Gallitelli, D., Di Franco, A., Vovlas, C., and Kaper, J. M. 1988. Infezioni miste del virus del mosaico del cetriolo (CMV) e di potyvirus in colture ortive di Puglia e Basilicata. Inf. Fitopatol. 12:57-64.

Gal-On, A., Kaplan, I., Roossinck, M. J., and Palukaitis, P. 1994. The cinetics of infection of zucchini squash by Cucumber mosaic virus indicate a function for RNA 1 in virus movement. Virology 205:280-289.

Guo, H. S., and Ding, S. W. 2002. A viral protein inhibits the long range signaling activity of the gene silencing signal. EMBO (Eur. Mol. Biol. Organ.) J. 21:398-407.

Hull, R. 2002. Matthews' Plant Virology, 4th ed. Academic Press, San Diego, CA, U.S.A.

Kaper, J., M., and Tousignant, M. 1984. Viral satellites: Parasitic nucleic acids capable of modulating disease expression. Endeavour New Ser. 8:194-200.

Lakatos, L., Csorba, T., Pantaleo, V., Chapman, E. J., Carrington, J. C., Liu, Y. P., Dolja, V. V., Calvino, L. F., Lopez-Moya, J. J., and Burgyan, J. 2006. Small RNA binding is a common strategy to suppress RNA silencing by several viral suppressors. EMBO (Eur. Mol. Biol. Organ.) J. 25:2768-2780.

Lewsey, M., Robertson, F.C., Canto, T., Palukaitis, P., and Carr, J. P. 2007. Selective targeting of miRNA-regulated plant development by a viral counter-silencing protein. Plant J. 50:240-252

Lewsey, M., Surette, M., Robertson, F. C., Ziebell, H., Choi, S. H., Ryu, K. H., Canto, T., Palukaitis, P., Payne, T., Walsh, J. A., and Carr J. P. 2009. The role of the Cucumber mosaic virus $2 \mathrm{~b}$ protein in viral movement and symptom induction. Mol. Plant-Microbe Interact. 22:642654.

Li, F., and Ding, S. W. 2006. Virus counterdefense: Diverse strategies for evading the RNA-silencing immunity. Annu. Rev. Microbiol. 60:503531.

Li, W. X., and Ding, S. W. 2001. Viral suppressors of RNA silencing. Curr. Opin. Biotechnol 12:150-154.

Livak, K. J., Schmittgen, T. D. 2001. Analysis of relative gene expression data using real-time quantitative PCR and the $2^{\bullet \Delta C \mathrm{Ct}}$ method. Methods 25:402-408

Lot, H., Marrou, J., Quiot, J. B., and Esvan, C. H. 1972. Contribution à l'étude du virus de la Masaique du cocombre (CMV). II. Méthode rapide de purification du virus. Ann. Phytopathol. 4:25-38.

Marathe, R., Anandalakshmi, R., Smith, T. H., Pruss, G. J., and Vance, V. B. 2000. RNA viruses as inducers, suppressors and targets of post-transcriptional gene silencing. Plant Mol. Biol. 43:295-306.

Martin, S., and Elena, S. F. 2009. Application of the game theory to the interaction between plant viruses during mixed infections. J. Gen. Virol. 90:2815-2820.

Mérai, Z., Kerényi, Z., Kertész, S., Magna, M., Lakatos, L., and Silhavy, D. 2006. Double-stranded RNA binding may be a general plant RNA viral strategy to suppress RNA silencing. J. Virol. 80:5747-5756.

Nelson, R. S., and van Bel, A. J. E. 1998. The mystery of virus trafficking into, trought and out of the vascolar tissue. Prog. Bot. 59:476-533.

Owen, J., and Palukaitis, P., 1988. Characterization of Cucumber mosaic virus. I. Molecular heterogeneity mapping of RNA 3 in eight CMV strains. Virology 166:495-502.

Paciolla, C., Dipierro, N., Mulè, G., Logrieco, A., and Dipierro S. 2004. The mycotoxins beauvericin and T-2 induce cell death and alteration to the ascorbate metabolism in tomato protoplasts. Physiol. Mol. Plant Pathol. 65:49-56.

Palukaitis, P. 1988. Pathogenicity regulation by satellite RNAs of cucumber mosaic virus: Minor nucleotide sequence changes alter host responses. Mol. Plant-Microbe Interact. 1:175-181.

Palukaitis, P., and Garcia-Arenal, F. 2003. Cucumoviruses. Adv. Virus Res. 62:241-323.

Palukaitis, P., and Kaplan, I. B. 1997. Synergy of virus accumulation and pathology in transgenic plants expressing viral sequences. Pages 77-84 in: Virus-Resistant Transgenic Plants: Potential Ecological Impact. M. Tepfer and E. Balázs, eds. Springer-Verlag, Berlin.
Poolpol, P., and Inouye, T. 1986. Enhancement of cucumber mosaic virus multiplication by zucchini yellow mosaic virus in doubly infected cucumber plants. Ann. Phytopathol. Soc. Jpn. 52:22-30.

Pruss, G., Ge, X., Shi, X. M., Carrington, J. C., and Vance, B. V. 1997. Plant viral synergism: The potyviral genome encodes a broad range pathogenicity enhancer that trans-activates replication of heterologous viruses. Plant Cell 9:859-868.

Qi, Y., Zhong, X, Itaya, A., and Ding, B. 2004. Dissecting RNA silencing in protoplasts uncovers novel effects of viral suppressors on the silencing pathway at the cellular level. Nucleic Acids Res. 32:e179.

Qu, F., Ye, X. H., Hou, G. C., Sato, S., Clemente, T. E., and Morris, T. J. 2005. RDR6 has a broad-spectrum but temperature-dependent antiviral defense role in Nicotiana benthamiana. J. Virol. 79:15209-15217.

Ryabov, E. V., Fraser, G., Mayo, M. A., Barker, H., and Taliansky, M. 2001. Umbravirus gene expression helps Potato leafroll virus to invade mesophyll tissues and to be transmitted mechanically between plants. Virology 286:363-372.

Ryang, B.-S., Kobori, T., Matsumoto, T., Kosaka, Y., and Ohki, S. T. 2004 Cucumber mosaic virus $2 \mathrm{~b}$ protein compensates for restricted systemic spread of Potato virus $Y$ in doubly infected tobacco J. Gen. Virol. 85:3405-3414.

Rochow, W. F. 1072. The role of mixed infections in the transmission of plant viruses by aphids. Annu. Rev. Phytopathol. 10:101-124.

Roth, B. M., Pruss, G. J., and Vance, V. B. 2004. Plant viral suppressors of RNA silencing. Virus Res. 102:97-108.

Sáenz, P., Salvador, B., Simón-Mateo, C., Kasschau, C. K., Carrington, J. C., and García, J. A. 2002. Host-specific involvement of the HC protein in the long-distance movement of potyviruses. J. Virol. 76:1922-1931.

Soards, A. J., Murphy, A. M., Palukaitis, P., and Carr, J. P. 2002. Virulence and differential local and systemic spread of Cucumber mosaic virus in tobacco are affected by the CMV 2b protein. Mol. Plant-Microbe Interact. 15:647-653.

Szittya, G., Silhavy, D., Molnar, A., Havelda, Z., Lovas, A., Lakatos, L., Banfalvi, Z., and Burgyan, J. 2003. Low temperature inhibits RNA silencing-mediated defence by the control of siRNA generation. EMBO (Eur. Mol. Biol. Organ.) J. 22:633-640.

Takebe, I., Otsuki, Y., and Aoki, S. 1968. Isolation of tobacco mesophyll cells in intact and active state. Plant Cell Physiol. 9:15-124.

Thompson, S., Fraser, R. S. S., and Barden, K. L. 1988. A beneficial effect of trypsin on the purification of Turnip mosaic virus (TuMV) and other potyviruses. J. Virol. Methods 20:57-64.

Vance, V., and Vaucheret, H. 2001. RNA silencing in plants-defense and counterdefense. Science 292:2277-2280.

Voinnet, O. 2001. RNA silencing as a plant immune system against viruses. Trends Genet. 17:449-459.

Wang, Y., Gaba, V., Yang, J., Palukaitis, P., and Gal-on, A. 2002. Characterization of synergy between Cucumber mosaic virus and potyviruses in cucurbit hosts. Phytopathology 92:51-58.

Wang, Y., Lee, K. C., Gaba V., Wong, S. M., Palukaitis, P., and Gal-On, A. 2004. Breakage of resistance to Cucumber mosaic virus by co-infection with Zucchini yellow mosaic virus: Enhancement of CMV accumulation independent of symptom expression. Arch. Virol. 149:379-396.

Wahyuni, W. S., Dietzgen, R. G., Hanada, K., and Francki, R. I. B. 1992. Serological and biological variation between and within subgroup I and II strains of Cucumber mosaic virus. Plant Pathol. 41:282-297.

Wege, C., and Siegmund, D. 2007. Synergism of a DNA and an RNA virus: Enhanced tissue infiltration of the begomovirus Abutilon mosaic virus (AbMV) mediated by Cucumber mosaic virus (CMV). Virology 357:10-28.

Zeng, R., Liao, Q., Feng, J., Li, D., and Chen, J. 2007. Synergy between Cucumber mosaic virus and Zucchini yellow mosaic virus on Cucurbitaceae hosts tested by real-time reverse transcription-polymerase chain reaction. Acta Biochim. Biophys. Sin. (Shanghai) 39:431-437.

Zitter, T. A. 1970. Titers of two virus diseases of celery affecting field spread. Phytopathology 60:1321. 